\title{
A revision of Brady's 1869 study of the Ostracoda of Hong Kong
}

\author{
ROBIN WHATLEY \& ZHAO QUANHONG \\ Geology Department, University College of Wales, Aberystwyth, UK \& \\ Department of Marine Geology, Tongji University, Shanghai, China
}

\begin{abstract}
This paper is a revision of Brady's 1869 study of the Ostracoda of Hong Kong in 'Les Fonds de la Mer'. In this he described the following nine new species: Cytherella cingulata, Bairdia elegans, Bythocythere orientalis, Loxoconcha sinensis, L. hastata, $C y t h e r i d e a$ impressa, Cythere cymba, C. euplectella and C. salebrosa. A detailed reappraisal of Brady's original material which is deposited in the Hancock Museum, Newcastle-uponTyne, UK, and the Centre d'Etudes et de Recherches Scientifiques, Biarritz, France has revealed that the specimens of $L$. hastata are apparently lost. Holotypes and lectotypes have been designated by the authors for the other eight species. Those species which were subsequently recorded by Brady (1880) in the Challenger Report, such as $C$. cingulata, $B$. orientalis, $L$. sinensis and $C$. euplectella are demonstrated not to be conspecific with their original types first described in 1869. The following 10 species, Bythoceratina virgatella $\mathrm{Hu}$, 1983 and B. cassidoidea Zhao, 1985; Cyprideis yehi Hu \& Yeh, 1978, Sinocytheridea sinensis Hou, 1978, S. latiovata Hou \& Chen, 1982, S. longa Hou \& Chen, 1982 and Eucytheridea sinobesani Hu, 1984: Cythereis subconvexa Kajiyama, 1913 and Aurila miii Ishizaki, 1968; Cythereis assimilis Kajiyama, 1913 are placed by the authors in the synonymies of Brady's $B$. orientalis, C. impressa, C. cymba and C. salebrosa respectively.
\end{abstract}

\section{INTRODUCTION}

G. S. Brady, the first worker to study the marine ostracods of China, in 1869 reported on an ostracod fauna consisting of 16 species from Hong Kong in 'Les Fonds de la Mer'. He described and illustrated the following nine new species: Bairdia elegans, Cythere cymba, C. euplectella, C. salebrosa, Cytheridea impressa, Loxoconcha hastata, L. sinensis, Bythocythere orientalis and Cytherella cingulata, and listed the following eight species: Bairdia subdeltoidea (Münster, 1830), Cythere cerebralis Brady, 1868, C. cribriformis Brady, 1866, C. crispata Brady. 1868, C. darwinii Brady, 1868, C. hodgii Brady, 1865, Pontocypris davisoni Brady, 1868 and Xestoleberis aurantia (Baird, 1838).

However, the description of some of his new species and the illustration provided in this paper are inadequate by modern standards and have been responsible for both taxonomic and ecological confusion by some subsequent authors. Two principal types of confusion have occurred. Firstly, some species names have been used by subsequent authors for species clearly not conspecific with Brady's type material. Brady himself provides an example. The species described by Brady in 1880) from the Challenger Expedition such as Bythocythere orientalis, Cythere euplectella. Loxoconcha sinensis and Cytherella cingulata are certainly not the same as those species first described by Brady in 1869 from Hong Kong. Secondly, there have been several synonymous species erected by later workers, such as Cythereis assimilis Kajiyama, 1913. Cythereis subconvexa Kajiyama, 1913 and Aurila miii Ishizaki. 1968, Cyprideis yehi $\mathrm{Hu} \&$ Yeh, 1978, Sinocytheridea sinensis Hou, 1978, S. latiovata Hou \& Chen, 1982, S. longa Hou \& Chen, 1982 and Eucytheridea sinobesani $\mathrm{Hu}, 1984$, Bythoceratina virgatella $\mathrm{Hu}, 1983$ and $B$. cassidoidea Zhao,1985. These are synonyms of Brady's Cythere salebrosa, C. cymba, Cytheridea impressa and Bythocythere orientalis respectively.

In order to rectify this state of confusion, it proved necessary to restudy Brady's original material, to designate lectotypes, to modernise and amend some description and to publish SEM illustrations. These are the principal aims of this paper.

\section{BRADY'S TYPE MATERIAL}

Brady's 1869 original ostracod collection from Hong Kong is deposited in both the Hancock Museum, Newcastle-upon-Tyne, UK (HMNT) and the Centre d'Etudes et de Recherches Scientifiques, Biarritz, France (CERS). Most specimens are in the Hancock Museum where there are three of Brady's slides labelled with Hong Kong as their locality, and each slide contains specimens of $3-4$ species. Brady's identification on slide no. 2.05.31 is Bythocythere orientalis, Cythere euplectella, C. salebrosa and Cythereidea impressa; on slide no. 20.05 .32 is Bairdia elegans, $B$. subdeltoidea and Cytherella cingulata; on slide no 2.05.33 Cythere cymba, Loxoconcha hastata and $L$. sinensis. In 1967, McKenzie removed some specimens of the following species from Brady's origin- 
al slides to new separate slides: $C$. cingulata (no. 1.08.32), B. orientalis (no. 1.35.35), B. elegans (no. 1.14.35), C. euplectella (no. 1.15.15), C. impressa (no. 1.23 .44 ) and $L$. sinensis (no. 1.46.46). Additionally, there are another three of Brady's original slides (nos. $1.08 .06,1.11 .10,1.12 .05)$ on which the identification is Cythere cerebralis, $C$. cribriformis and $C$. darwinii respectively. Their locality, however, is doubtful as each slide was also labelled with two place names, "Hong Kong and Java" or "Hong Kong and Java Sea". It is impossible, therefore, to be certain which specimens are really from Hong Kong. For this reason, the authors have not made use of this latter material in this paper.

A few specimens of five of the species are deposited in the Centre d'Etudes et de Recherches Scientifiques. These are B. elegans (no. 68.22.63), C. euplectella (no. 68.22.52), C. salebrosa (no. 68.21.40), C. cingulata (no. 68.18.59) and Xestoleberis aurantia (no. 68.20.69).

The authors could not find Cythere crispata nor $C$. hodgii in the Brady Collection from Hong Kong at the Hancock Museum, or the British Museum (N.H.). Fortunately, it seems that the original material of Brady's new species is preserved much better than that of other species.

\section{SYSTEMATIC DESCRIPTIONS}

Phylum Crustacea Pennant, 1777

Class Ostracoda Latreille, 1806

Order Podocopida Müller, 1894

Suborder Platycopina Sars. 1866

Family Cytherellidae Sars, 1866

Genus Cytherelloidea Alexander, 1929

Cytherelloidea cingulata (Brady) 1869

(Pl. 1, figs. 1, 2)

1869 Cytherella cingulata Brady: 159, pl. 16, figs. $24,25$.

1880 Cytherella cingulata Brady; (pars) Brady: 177, pl. 43, figs. 1a-d.

1964 Cytherelloidea cingulata Brady; Keij: 419. 420 , pl. 1, figs. $4-8$.

?1948 Cytherelloidea cingulata Brady; Kingma: 65, pl. 6, fig. 10 .

non 1880 Cytherella cingulata Brady (pars); Brady: 177, pl. 43, figs. le-g, 2a-d.

non 1983 Cytherelloidea cingulata (Brady); Gou et al.; 133, pl. 23, figs. 30, 31 .

Lectotype. Female RV (CERS 68.18.59).

Material. Two specimens of this species are separately deposited in the UK and France.

Dimensions (in mm). Length Height

$\begin{array}{llll}\text { Lectotype (CERS 68.18.59) } & \text { O RV } & 0.56 & 0.36\end{array}$

$\begin{array}{llll}\text { Paralectotype (HMNT 2.05.43) } & \text { Q LV } & 0.57 & 0.33\end{array}$

\section{Explanation of Plate 1}

Figs. 1-2. Cytherelloidea cingulata (Brady).

Fig. 1. Lectotype, $q$ RV (CERS 68.18.59), ext. lat. $(\times 103)$.

Fig. 2. Paralectotype, $q$ LV (HMNT 1.08.43), ext. lat. $(\times 105)$.

Figs. 3-7. Neonsidea elegans (Brady).

Fig. 3. Paralectotype, juv. LV (HMNT 1.15.21), est. lat. $(\times 85)$.

Fig. 4. Paralectotype, juv. RV (HMNT 1.15.22), int. $(\times 85)$.

Fig. 5. Paralectotype, juv. car. (HMNT 1.14.33), right lat. $(\times 85)$.

Fig. 6. Lectotype, car. (HMNT 1.15.19), right lat. $(\times 53)$.

Fig. 7. Paralectotype, LV (HMNT 1.15.20), int. $(\times 53)$.

Fig. 8-10. Sinocytheridea impressa (Brady).

Fig. 8. Paralectotype, $q$ car. (HMNT 1.23.44) right lat. $(\times 60)$.

Fig. 9. Lectotype, $q$ LV (HMNT 1.24.37), int. $(\times 60)$.

Fig. 10. Paralectotype, $q$ RV (HMNT 1.24.38), int. $(\times 60)$.

Fig. 11. Bythoceratina orientalis (Brady).

Fig. 11. Holotype, RV (HMNT 1.35.35), ext. lat. $(\times 65)$.

Figs. 12, 13. Xestoleberis hanaii Ishizaki, 1968.

Figs. 12, 13. $q$ opened carapace, (CERS 68.20.69): fig. 12, LV ext lat.; fig. 13, int. with instars $(\times 77)$. 


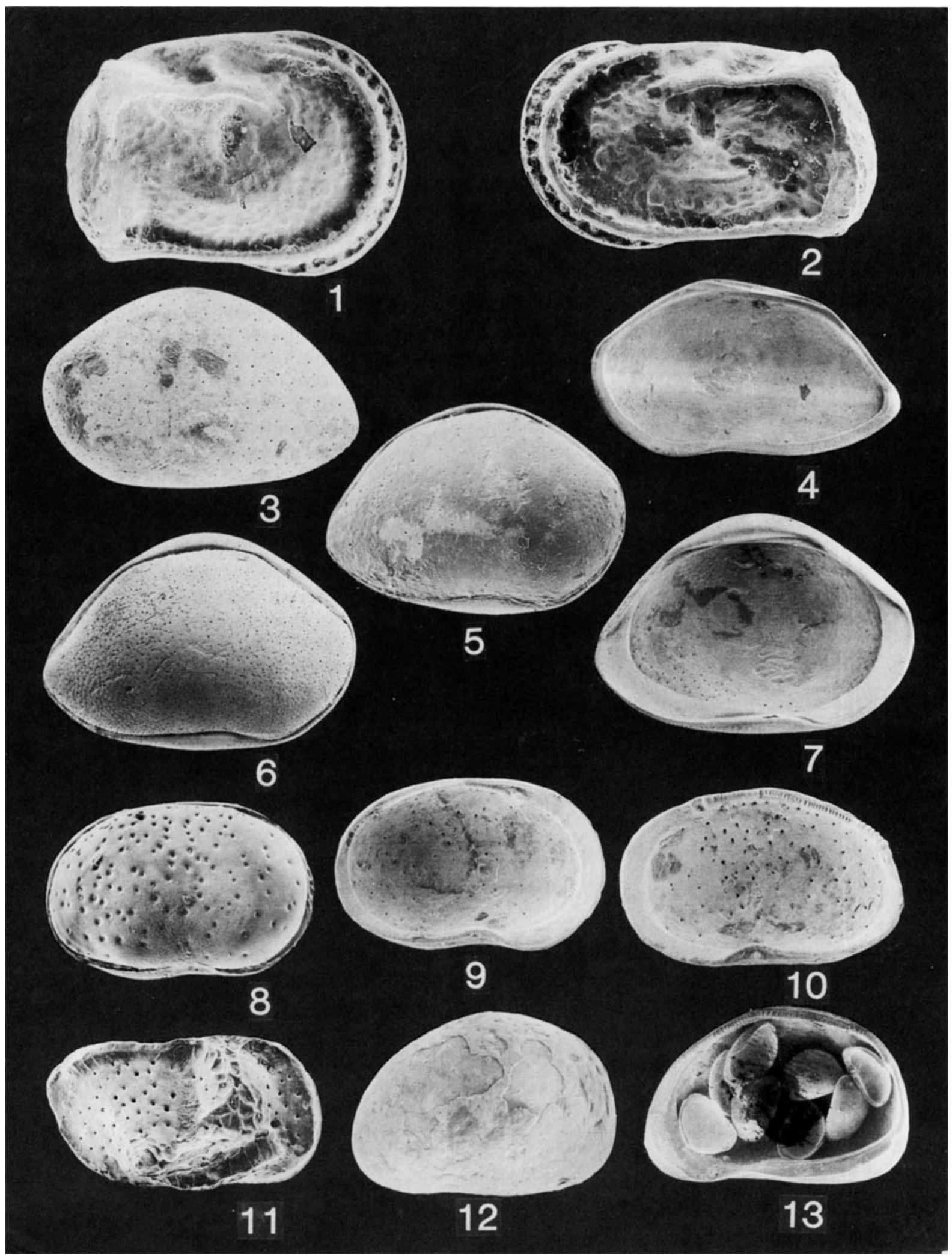


Diagnosis. Medium. surface covered by faint reticulation with a marginal rib which extends from the mid-dorsal margin along the anterior, ventral and posterior margins, becoming vertical posteriorly, a horizontal dorsal rib, which is about half the length of the carapace and which unites posterodorsally with the vertical posterior marginal rib, and a very weak, short, narrow, horizontal rib which extends just below the muscle-scar depression.

Remarks. As the specimen illustrated by Brady (1869) is a right valve, it is reasonable to designate the right of Brady's two original valves as the lectotype and the left one as the paralectotype. Of the specimens reported by Brady (1880) from Hong Kong. Indonesia and Australia, only those (pl. 43. figs. 1a-d) are conspecific with his 1869 type material. The others (pl. 43, figs. le-g. $2 a-d)$ are obviously different species due to their different ornamentation. The specimens described under the name of $C$. cingulata by Gou et al. (1983). possessing a continuous marginal rib, are virtually the same as Brady's 1880) specimens (pl. 43, figs. le-g) which are clearly not $C$. cingulata. Kingma (1948) illustrated one specimen from Indonesia which is probably not $C$. cingulata since it has a long prominent horizontal rib below the muscle-scar depression.

Distribution. South China Sea: Hong Kong and off Borneo, Recent.

Suborder Podocopina Sars, 1866

Superfamily Bairdiacea Sars, 1888 Family Bairdiidae Sars. 1888

Genus Neonesidea Maddocks, 1969

Neonesidea elegans (Brady) 1869

(PI. 1, figs. 3-7)

1869 Bairdia elegans Brady: 156, pl. 16, figs. 11, 12.

1869 Bairdia subdeltoidea (Münster); Brady: 155

?1978 Bairdia haikangensis Guan, in Guan et al.: 155. pl. 38, figs. 8-11.

?1981 Bairdia haikangensis Guan; Gou et al.; 148, pl. 74, figs. 1-4.

?1983 Bairdia haikangnesis Guan; Gou et al.; 14, pl. 1. figs. 1-9.

?1985 Neonesidea haikangensis (Guan); Wang \& Zhao; 82, fig. 16; pl. 6, figs. 4, 5 .

?1985 Neonesidea haikangensis (Guan); Zhao et al.; 204, fig. 21: pl. 19, figs. 3, 4 .

Lectotype. Adult carapace (HMNT 1.15.19).

Material. Brady's type specimens of this species are deposited in both the UK and France. In the Hancock Museum, Brady's original slide no. 2.05.33 contains two carapaces and three valves which are designated as the lectotype and paralectotypes and have been removed to new slides. The French slide no. 68.22.63 contains one carapace and one RV which are both juveniles.

$\begin{array}{lccc}\begin{array}{l}\text { Dimensions (in mm). } \\ \text { Lectotype }\end{array} & \text { Length } \text { Height } & \text { Width } \\ \begin{array}{l}\text { (HMNT 1.15.19) car. } \\ \text { Paralectotype }\end{array} & 1.00 & 0.68 & 0.52 \\ \quad \text { (HMNT 1.15.20) LV } & 1.02 & 0.70 & \\ \begin{array}{l}\text { Paralectotype } \\ \text { (HMNT 1.14.33) car. }\end{array} & 0.59 & 0.38 & 0.29 \\ \begin{array}{l}\text { Paralectotype } \\ \text { (HMNT 1.15.21) LV }\end{array} & 0.62 & 0.39 & \\ \begin{array}{l}\text { Paralectotype } \\ \text { (HMNT 1.15.22) RV }\end{array} & 0.61 & 0.35 & \end{array}$

Diagnosis. RV and LV differ in shape and size. LV larger and overlapping RV along periphery, most strongly along dorsal and ventral margins; almondshaped in lateral view with highly arched dorsal margin and slightly convex ventral margin; posterior upturn not exhibited. RV typically bairdoid in outline with straight and slightly oblique dorsal margin, slightly concave ventral margin and upturned posterior margin. A row of small nodelike denticles occurs along the posteroventral margin of LV. Surface finely punctate. Remarks. Both the names Bairdia elegans and $B$. subdeltoidea were labelled on Brady's original slide no. 2.05.33. It transpires that the specimens of this slide represent different ontogenetic stages of the same species, $B$. elegans, containing one adult carapace, one adult left valve. one immature carapace and two immature valves. By comparing Brady's 1869 illustration (pl. 16, figs. 11, 12) with our figure of a juvenile (P1. 1, fig. 5) it is evident that B. elegans was erected by Brady based on the juvenile. Brady (1869) did not illustrate $B$. subdeltoidea and we assume that he must have misidentified the adults of $B$. elegans as this species. B. subdeltoidea, a European species, is very similar to the present species, but the RV is a little lower and slightly concave ventrally and also lacks denticles on the posteroventral margin of the left valve. B. haikangensis Guan, 1978, probably synonymous with $B$. elegans, only differs from Brady's original material in lacking the marginal denticles, which are also less well developed in the adult of $B$. elegans. Distribution. Hong Kong, continental shelves off eastern and south eastern China (?). Recent; south eastern China (?). Pliocene.

Superfamily Cytheracea Baird, 1850

Family Cytherideidae Sars, 1925

Genus Sinocytheridea Hou, in Hou et al., 1982 Sinocytheridea impressa (Brady) 1869

(Pl. 1, figs. 8-10)

1869 Cytheridea impressa Brady: 158, pl. 16. figs. 13. 14.

1978 Cyprideis vehi Hu \& Yeh: 157-159. pl. 3. figs. $10-13$.

1978 Sinocytheridea sinensis Hou, in Guan et al.: 240. pl. 65. figs. $1-5$. 
1982 Sinocytheridea latiovata Hou \& Chen. in Hou et al.: 164,165 , pl. 72 , figs. 10-20.

1982 Sinocytheridea longa Hou \& Chen. ibid.: 165. pl. 72, figs. 1-9.

1984 Eucytheridea sinobesani $\mathrm{Hu}:$ 76, pl. 10, figs. 27. 28.

Lectotype. Female LV (HMNT 1.24.37).

Material. Brady's original slide no. 1.24 .38 contained one carapace, one RV and one LV, which are designated as the lectotype and paralectotypes by the authors and removed to new separate slides. Brady"s original slide now has no specimens of this species. Dimensions (in mm). Length Height Width Lectotype

$\begin{array}{ccccc}\quad \text { (HMNT 1.24.37) } & \text { Q LV } & 0.77 & 0.47 & \\ \begin{array}{c}\text { Paralectotype } \\ \text { (HMNT 1.24.38) }\end{array} & \text { qRV } & 0.74 & 0.45 & \\ \begin{array}{c}\text { Paralectotype } \\ \text { (HMNT 1.23.44) }\end{array} & \text { q car. } & 0.74 & 0.46 & 0.34\end{array}$

Diagnosis. This species is characterised by its modified antimerodont hinge with a conspicuous anti-slip toothlet anteriorly in the LV and in being avestibulate.

Remarks. The material on which Brady erected $C$. impressa is all female. Of the five synonymous species. $C$. yehi, $S$. sinensis and $S$. latiovata are the female dimorphs of the present species, and $S$. longa and $E$. sinobesani are males which differ from the females only in being more elongate and slimmer.

Distribution. Pliocene to Recent of eastern China, Pleistocene (?) of Japan (Ishizaki, 1984): Recent representatives occur widely in shelf, littoral, estuaries, marshes. tidal pools and channels of the supralittoral zone along the entire coast of China, in water depths ranging from middle shelf $(50-100 \mathrm{~m})$ to supralittoral and in salinities from about $2 \%$ to normal sea water. The authors have recently found a few specimens of this species from bottom sediments in the estuary of the Sedili River, southern Malaya.

Family Bythocytheridae Sars. 1926

Genus Bythoceratina Sars, 1866

Bythoceratina orientalis (Brady) 1869

(Pl. 1, fig. 11)

1869 Bythocythere orientalis Brady: 159. pl. 16. figs. 21-23.

1982 Bythoceratina sp., Yajima: 126, pl. 13, fig. 16.

1983 Bythoceratina virgatella $\mathrm{Hu}: 160,161, \mathrm{pl} .3$. figs. $1-3,7,9,10$; text-fig. 11 .

1985 Bythoceratina cassidoidea Zhao. in Wang \& Zhao: pl. 8, fig. 18.

non 1880 Bythocythere orientalis Brady; Brady: 141, 142 , pl. 16 , figs. $6 a-d$; pl. 32, figs. $2 a-c$.

Holotype. RV (HMNT 1.35.35).

Material. Only one RV was found which was removed in 1967 by McKenzie from Brady's original slide no.
2.05.31 to the present slide. and it has to be considered as the holotype of this species.

Dimensions (in $\mathrm{mm}$ ).

Holotype (HMNT 1.35.35) RV

Length Height

$0.71 \quad 0.36$

Diagnosis. This species is characterised by its strong posteroventral spine. from its base two long and prominent ventral ribs extend anteriorly and two short and weak ribs posteriorly. Median sulcus distinct; anterior lobe relatively swollen and covered by weak reticulation; posterodorsal rib prominent, extending from above the anterior lobe to just in front of the caudal process.

Remarks. The specimens reported by Brady (1880) from Hong Kong and the Torres Straits are not conspecific with Brady's 1869 type specimen. On examining Brady's 1880 specimen of Hong Kong which is deposited in the British Museum (Natural History). the authors found it to belong to $B$. hanaii Ishizaki. 1968 which is characterised by a thick ventral rib. The specimens from the Torres Straits, bearing a prominent mid-dorsal node, probably belong to Nodobythere Schornikov. 1980.

Family Loxoconchidae Sars, 1925

Genus Loxoconcha Sars. 1866

Loxoconcha sinensis Brady. 1869

(Pl. 2, figs. 1-5)

1869 Loxoconcha sinensis Brady: 158. pl. 16. figs. 17,18 .

non 1880 Loxoconcha sinensis Brady: 120, pl. 29. figs. $2 \mathrm{a}-\mathrm{d}$.

non 1948 Loxoconcha sinensis Brady; Kingma: 91, pl. 11, fig. 2.

non 1983 Loxoconcha sinensis Brady; Gou et al.: 71. pl. 18, figs. 28, 29.

non 1985 Loxoconcha sinensis Brady: Wang \& Zhao: pl. 8. fig. 6.

non 1985 Loxoconcha sinensis Brady: Zhao et al.: 203, fig. 17; pl. 20, fig. 10 .

Lectotype. Female carapace (HMNT 1.58.01).

Material. One carapace, three RV and three LV only are deposited in the Hancock Museum and are removed from Brady's original slide no. 2.05.32 to their present individual slides.

Dimensions (in $\mathrm{mm}$ ). Length Height Width

Lectotype

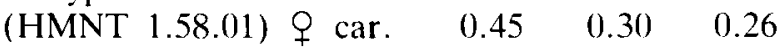

Paralectotype

$\begin{array}{llll}\text { (HMNT 1.46.41) O } & \text { LV } & 0.49 & 0.27\end{array}$

Paralectotype

$\begin{array}{lllll}(\text { HMNT 1.56.14) } q \text { RV } & 0.48 & 0.28\end{array}$

Diagnosis. Oblong to ovate in lateral view with subparallel dorsal and ventral margins. Surface coarsely reticulate with two relatively prominent ribs ventrally: the outer one parallel to the ventral margin and the inner one slightly concave posteriorly. The posterodorsal area is markedly swollen and on it the muri become 
thickened and more elevated, and in dorsal view the posterior margin is broadly obtuse. The male is more elongate and slimmer than the female with a diagnostic small patch of fine punctae just above the posterodorsal swelling.

Remarks. Both the names Loxoconcha sinensis and $L$. hastata are written on Brady's original slide no. 2.05.32, but only specimens of the former species were found. No specimens of $L$. hastata were found anywhere in Brady's Collection and they are, therefore, presumed lost. $L$. sinensis and $L$. hastata are not easily confused on the basis of their original illustrations. The latter is much higher and the posteroventral margin is markedly convex. We have checked the specimens in the Challenger collection in both the British Museum and the Hancock Museum, under the name of $L$. sinensis, recorded by Brady (1880) from Hong Kong and Japan, and found none of them to be conspecific with the type as they all lack the diagnostic posterodorsal swelling. It is evident, therefore, that those specimens were subsequently misidentified by Brady himself. This misidentification has influenced subsequent authors, notably Kingma (1948), Gou et al. (1983). Wang \& Zhao (1985) and Zhao et al. (1985) in their erroneous intepretation of this species. All of these authors have used the name $L$. sinensis for species which are not conspecific with Brady's original material from Hong Kong.

Distribution. Only Hong Kong. Recent.
Family Hemicytheridae Puri, 1953

Genus Mutilus Neviani, 1928

Mutilus salebrosa (Brady) 1869

(Pl. 2. figs. 13, 14)

1869 Cythere salebrosa Brady: 158, pl. 16. figs. $8-10$.

1913 Cythereis assimilis Kajiyama: 14, pl. 1, figs. 76.

1980 Mutilus assimilus (Kajiyama); Okubo: 4(13-405, figs. 5, 7a, b, 11a-d.

1982 Robustaurila assimilis (Kajiyama): Yajima: 212, pl. 13, figs. 6-8.

non 1982 Mutilus assimilis (Kajiyama); Hou et al:: 178-179, pl. 75, figs. 18-22.

Holotype. RV (CERS 68.21.40).

Material. Brady's original specimens were deposited in both the UK and France. However, the material in the Hancock Museum is deemed lost as no specimen was found on the slide no. 2.05.31 labelled Cythere salebrosa nor in any of the other slides from Hong Kong. Only one $\mathrm{RV}$ is now preserved in France and it is designated as the holotype of this species.

Dimensions (in $\mathrm{mm}$ ).

Holotype (CERS 68.21.40) RV

Length Height

$0.72 \quad 0.41$

Diagnosis. Carapace inflated medianly; coarsely and irregularly reticulate suface characterised by sub-alar ventrolateral rib and radial ribs.

Remarks. Brady's 1869 illustration was drawn based on the LV which is thought to be lost. compared with which the present specimen is a little lower and more elongate which represents the major difference be-

\section{Explanation of Plate 2}

Figs. 1-5. Loxoconcha sinensis Brady.

Fig. 1. Paralectotype, $q$ RV (HMNT 1.56.14), ext. lat. $(\times 110)$.

Fig. 2. Paralectotype. $\sigma^{\prime}$ LV (HMNT 1.46.41), ext. lat. $(\times 115)$.

Figs. 3-5. Lectotype. $q$ opened carapace (HMNT 1.58.01): fig. 3, dors; fig. 4, LV ext. lat.; fig. 5, RV int. (all $\times 110)$.

Figs. 6-8. ? Lankacythere euplectella (Brady).

Fig. 6. Paralectotype, car. (CERS 68.22.53), right lat. $(\times 65)$.

Fig. 7. Paralectotype, LV (HMNT 1.57.38), ext. lat. $(\times 67)$.

Fig. 8. Lectotype, RV (HMNT 1.15.17), int. $(\times 67)$.

Figs. 9-12. Aurila cymba (Brady).

Figs. 9-11. Lectotype, $\sigma^{7}$ opened carapace (HMNT 1.57.36): fig. 9. LV int.; fig. 10, LV ext. lat.; fig. 11, RV ext. lat. (all $\times 70)$.

Fig. 12. Paralectotype, $q$ car. (HMNT 1.57.38). right lat. $(\times 67)$.

Figs. 13, 14. Mutilus salebrosa (Brady).

Fig. 13, 14. Holotype, RV (CERS 68.21.40): fig. 13. ext. lat.; fig. 14 oblique dorso-lat. $(\times 65)$. 


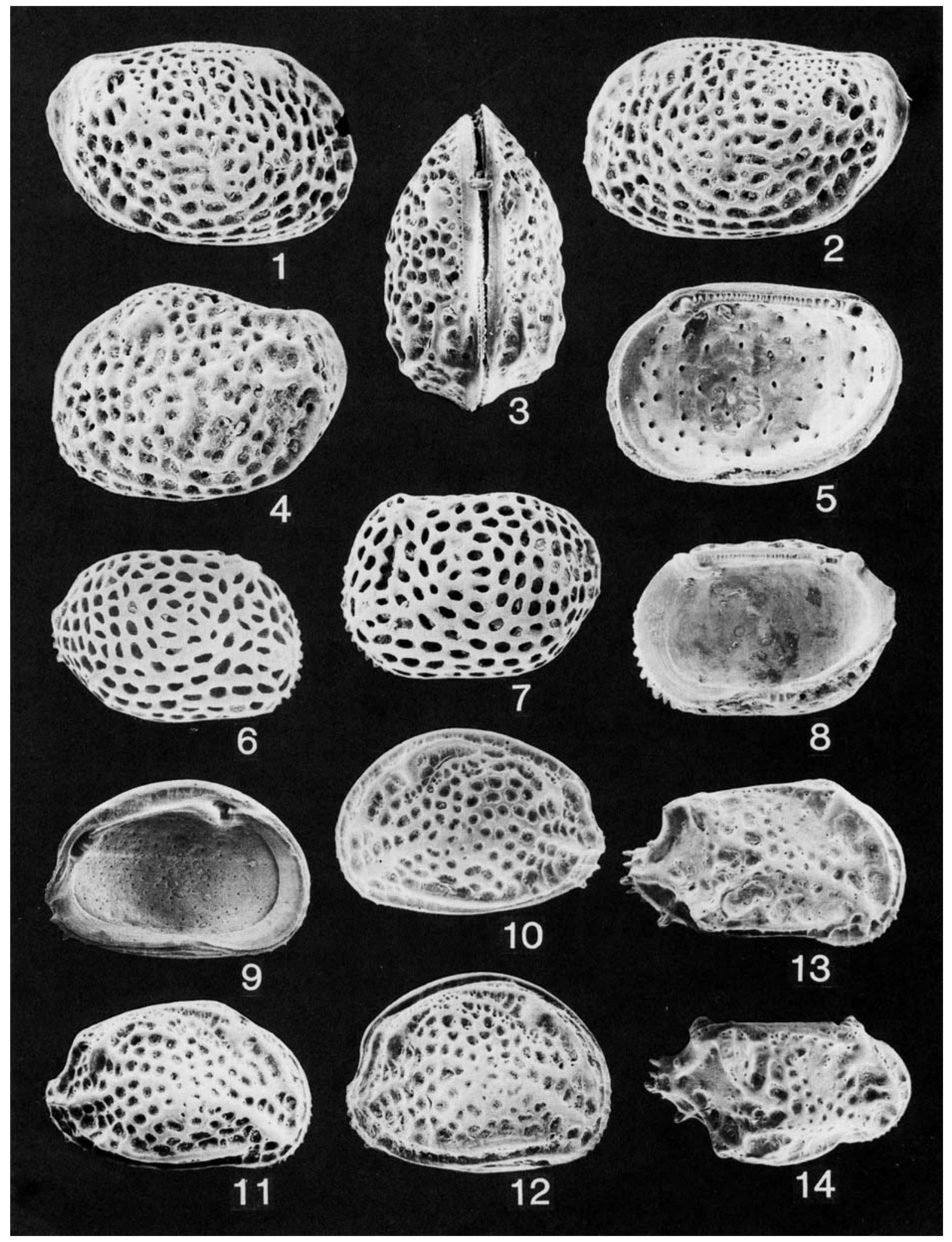


tween LV and RV. From the material of Okubo (1980) and Yajima (1982) which agree well with the present type, we believe that Kajiyama's $C$. assimilis is conspecific with the present species. Bearing weaker and more regular reticulation, the material of Hou et al. (1982) is quite different from $M$. salebrosa and probably belongs to $M$. ishizaki Okubo, 1980.

Distribution. Hong Kong, Recent; Japan, late Pleistocene to Recent.

Genus Aurila Pokorny, 1955

Aurila cymba (Brady) 1869

(Pl. 2, figs. 9-12)

1869 Cythere cymba Brady: 157, pl. 16, figs. 1-4.

1880 Cythere cymba Brady; Brady: 80, 81, pl. 20, figs. $5 \mathrm{a}-\mathrm{f}$.

1913 Cythereis subconvexa Kajiyama: 14, pl. 1, figs. 74, 75.

1968 Aurila miii Ishizaki: 22, pl. 1, fig. 9; pl. 4, figs. 1, 2.

1976 Cythere cymba Brady; Puri \& Hulings: pl. 25. figs. 3-6.

1977 Aurila cymba (Brady); Hanai et al.; 42.

1980 Aurila subconvexa (Kajiyama); Okubo: 397399, figs. $2,7 \mathrm{~m}, \mathrm{n}, 9 \mathrm{a}-\mathrm{d}$.

1985 Aurila cymba (Brady); Zhao: pl. 2, fig. 4.

Lectotype. Male carapace (HMNT 1.57.36).

Material. In Brady's 1869 collection from Hong Kong this species comprises 12 carapaces and one RV which are all deposited in the Hancock Museum.

Dimensions (in $\mathrm{mm}$ ). Length Height Width

Lectotype

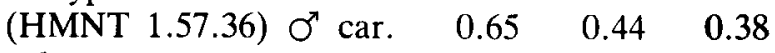

Paralectotype

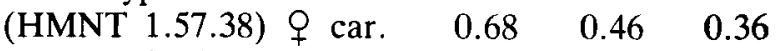

Diagnosis. Surface ornamented with concentric and rounded pits which become reticulations peripherally, long and prominent ventral marginal rib, anterior marginal rib which joins the eye-tubercle and extends to the mid-anterior part of the dorsal margin, short and curved posterodorsal rib, and radial ribs of which the anteroventral and post-median ones are most pronounced.

Remarks. On the basis of detailed comparisons, we are convinced that the material of $C$. cymba subsequently described by Brady himself in 1880 and refigured by Puri \& Hulings (1976), together with $A$. miii Ishizaki, 1968 and $A$. subconvexa (Kajiyama) 1913, are all conspecific with Brady's original material from Hong Kong.

Distribution. China, Pliocene Recent; Japan, Pleistocene to Recent.

Family Trachyleberididae Sylvester-Bradley, 1948 Genus Lankacythere Bhatia \& Kumar, 1979 ?Lankacythere euplectella (Brady), 1869 (PI. 2, figs. 6-8)
1869 Cythere euplectella Brady: 157, 158, pl. 16. figs. 5-7.

1985 Bicornucythere euplectella (Brady); Wang \& Zhao: pl. 7, fig. 18.

1985 Bicornucythere euplectella (Brady); Zhao et al.; 199, fig. 7; pl. 19, fig. 18.

non 1880 Cythere euplectella Brady; Brady: 96. pl. 25. figs. $3 \mathrm{a}-\mathrm{d}$.

non 1976 Cythere euplectella Brady; Puri \& Hulings: pl. 25, figs. 14-15.

Lectotype. RV (HMNT 1.15.17).

Material. Brady's specimens are deposited in both the UK and France. The Hancock Museum has one RV and one LV, which are removed from Brady's original slide no. 2.05.31 to their present slides. French slide (no. 68.22.52) labelled $C$. euplectella in fact contains one carapace of this species and one carapace of Neomonoceratina.

Dimensions (in $\mathrm{mm}$ ). Length Height Width Lectotype

$$
\begin{array}{lll}
\text { (HMNT 1.15.17) RV } & 0.65 & 0.41
\end{array}
$$

Paralectotype

$\begin{array}{lll}\text { (HMNT 1.15.15) LV } & 0.65 & 0.41\end{array}$

Paralectotype

$\begin{array}{llll}\text { (CERS 68.22.53) car. } & 0.65 & 0.40 & 0.46\end{array}$

Diagnosis. Medium, inflated, thick-shelled, subrectangular in lateral view with subparallel dorsal and ventral margins. Surface covered by concentric reticulation, consisting of ' $T$ '-shaped muri and deep fossae whose openings are slit-like in lateral view. Holamphidont hinge with stepped anterior tooth and bulb-like posterior tooth. Avestibulate; frontal scar single and rounded.

Remarks. This species is very readily identified by its diagnositic reticulation of ' $T$ '-shaped muri. C. euplectella illustrated by Brady (1880) and Puri \& Hulings (1976) has reticulation which lacks these characteristic muri and is evidently not conspecific with Brady's 1869 type material. We tentatively refer this species to Lankacythere Bhatia \& Kumar, 1979 based mainly on its hinge and its deep and concentric fossae, despite the fact that the posterodorsal rib, one of the diagnostic feature of this genus, is not developed.

Distribution. Recent, beside Hong Kong, it has been widely encountered in bottom sediments of the South and East China Seas (Wang \& Zhao, 1985; Zhao et al., 1985 ) and of the Malacca Straits (Whatley \& Zhao, in press).

Family Xestoleberidae Sars, 1928

Genus Xestoleberis Sars, 1928

Xestoleberis hanaii Ishizaki, 1968

(Pl. 1, figs. 12, 13)

1869 Xestoleberis aurantia (Baird); Brady: 155.

1968 Xestoleberis hanaii Ishizaki: 41, 42, pl. 9, figs. 1, 2. 
1977 Xestoleberis hanaii Ishazaki; Hanai, et al.: 66. 1985 Xestoleberi hanaii Ishizaki; Zhao: 198, 200. Material. One adult female carapace is deposited in Biarritz. This contains within it 6 juvenile carapaces of what are probably the 1st instar.

$\begin{array}{lccc}\text { Dimensions (in mm). } & \text { Length } & \text { Height } & \text { Width } \\ \text { CERS 68.28.69 } \sigma^{7} \text { car. } & 0.58 & 0.37 & 0.34\end{array}$

Remarks. This is the only species available for study in either the Hancock Museum or Biarritz of the eight species only listed by Brady (1869). The species clearly differs from the Recent North West European species, $X$. aurantia which has a well rounded posterior margin and an anteroventral process of the LV which strongly overlaps the RV.

Distribution. Japan, late Pleistocene to Recent; Kurile Islands of the USSR; China, Recent.

\section{ACKNOWLEDGEMENTS}

The authors would like to express their thanks to Dr. P. Davis, deputy curator of the Hancock Museum and Dr. A. Percier, Chief of the Centre d'Etudes et de Recherches Scientifiques, Biarritz, France for allowing us access to Brady's 1869 original specimens and for permission to photograph them. We also wish to thank Dr. J. E. Whittaker, Dr. G. Boxshall and Miss S. Halsey of the British Museum (N.H.) for arranging access to the Challenger collection. The manuscript was typed by Mrs. V. Grant, to whom our grateful thanks are extended.

\section{Manuscript received October 1986}

Revised manuscript accepted May 1987
Hanai, T., Ikeya, N.. Ishizaki, K., Sekiguchi, Y. \& Yajima, M. 1977. Checklist of Ostracoda from Japan and its adjacent seas. Univ. Mus. Univ. Tokyo Bull, 12, $110 \mathrm{pp}$.

Hanai, T.. Ikeya, N. \& Yajima, M. 1980. Checklist of Ostracoda from Southeast Asia. Univ. Mus. Univ. Tokyo Bull., 17, 242pp.

Hou Youtang Chen Techiung, Yang Hengren, Ho Junde, Zhou Quanchun \& Tian Muqu. 1981. Cretaceous Quaternary ostracode fauna from Jiangsu. Geological Publishing House Beijing, 298pp.

Hu Chung Hung. 1983. Ostracods from the Mannshan, Hengchun Penisula, Southern Taiwan. Petrol. Geol. Taiwan, 19, 149-178.

Hu Chung Hung \& Yeh Kuei Yu. 1978. Ostracod fauna from the Pleistocene Liushuang Formation in the Tainan area, Taiwan. Proc. Geol. Soc. China (Taiwan), 21, 151-162.

Kingma, J. T. Contribution to the knowledge of the Young Cenozoic Ostracoda from the Malayan region. Thesis Univ. Utrecht, $119 \mathrm{pp}$.

Okubo, I. 1980. Taxonomic study on Recent podocopid Ostracoda from the Inland Sea of Seto. Publ. Seto Mar. biol. Lab., 25(5/6), 389-443.

Puri, H. S. \& Hulings, N. C. 1976. Designation of lectotypes of some ostracods from the Challenger Expedition. Bull. Br. Mus. nat. Hist. (Zool.), 29(5), 251-315.

Wang Pinxian \& Zhao Quanhong. 1985. Ostracod distribution in bottom sediments of the East China Sea. In Wang Pinxian (Ed.), Marine micropaleaontology of China. China Ocean Press \& Springer-Verlag, 70-92.

Whatley, R. C. \& Zhao Quanhong. (In press). Recent Ostracoda of the Malacca Straits. Revta. esp. Micropaleont.

Zhao Quanhong. 1985. A study on distribution of Recent Coastal ostracod faunas of the East China Sea and the Yellow Sea. Acta Ocean. Sinica, 7(2), 194-204 (in Chinese).

Zhao Quanhong, Wang Pinxian \& Zhang Qinlan. 1985. Ostracoda in bottom sediments of the South China Sea off Guangdong Province, China: Their taxonomy and distribution. In Wang Pinxian (Ed.), Marine micropalaeontology of China, 196-217.

\section{REFERENCES}

Brady, G. S. 1869. Les entomostraces de Hong Kong. In Folin, L. De \& Perier, L. (Eds.), Les Fonds de la Mer, 1(1), 155-159, pl. 16.

Brady. G. S. 1880. Report on the Ostracoda dredged by H.M.S. Challenger during the years 1873-1876. Rep. Sci. Res. Voyage H.M.S. Challenger. Zoology, 1(3), Ostracoda. $184 \mathrm{pp}$.

Gou Yunsian. Chen Techiung. Guan Shaozeng, Jiang Yanwen. Liu Zongyun. Lai Xiahong. Wu Quingjun \& Chen Chaoyun. 1981. Ostracoda. In Tertiary Paleontology of north continental shelf of South China Sea. Guangdong Sci. Techn. Press, 138-187 (in Chinese).

Gou Yunsian. Zheng Shoying \& Huang Baoren. 1983. Pliocene ostracode fauna of Leizhou Peninsula and northern Hainan Island. Guangdong Province. Paleont. Sinica, new ser. B. 18. 134 pp. (In Chinese. with English abstract). Guan Shaozeng. Sun Quanying. Jiang Yanwen. Li Lingli. Zhang Xianqui. Yang Runling \& Feng Baiying. 1978. Ostracoda. In Paleontological atlas of Central and South China, Geological Publishing House, Beijing,4, 115-324 (in Chinese). 